\title{
Intensificação de sistemas de produção através da mecanização na região da Transamazônica: limites e possibilidades
}

\author{
Aquiles Simões \\ Professor do Núcleo de Estudos \\ Integrados sobre Agricultura Familiar, \\ Centro Agropecuário, Universidade \\ Federal do Pará - NEAF/CAP/UFPA.
}

\section{Resumo}

O presente estudo analisa o uso da mecanização nas condições reais dos agricultores familiares. Os resultados foram construídos na base de duas pesquisas complementares entre si: o acompanhamento do Projeto de Mecanização desenvolvido pela prefeitura do município de Altamira - PA e o levantamento de outras experiências desenvolvidas pelos agricultores no município de Uruará - PA. Verificou-se que o problema da manutenção da fertilidade do solo é um fator limitante à mecanização, ao lado da baixa remuneração do trabalho, da diminuição de interesse pela produção de culturas anuais, e da disponibilidade de área para continuar com a agricultura itinerante. As condições atuais dos sistemas agrários não permitem ainda a transição para a agricultura permanente ou a intensificação dos sistemas de produção a partir da mecanização. No entanto, os interesses da coletividade e a realização de estudos aprofundados com agricultores que vêm praticando tração animal poderão relativizar estes resultados.

\section{Palavras-Chave}

Amazônia - Mecanização - Agricultura Fertilidade do solo - Custos da mecanização - Tração animal.

\author{
Heribert Schmitz \\ Professor Visitante do Núcleo de Estudos \\ Integrados sobre Agricultura Familiar \\ - NEAF/CAP/UFPA e pesquisador associado do \\ Laboratório Agroecológico da Transamazônica \\ - LAET.
}

\section{Abstract}

This study focuses on the use of mechanisation within the context of smallholder farming. Research results are based on two complementary activities; a Mechanisation Project developed by Altamira Town Hall, Pará and a study of experiments developed by farmers in Uruará County, Pará. Research hypotheses were developed based on existing literature on the transition from migratory to fixed farming. The study confirmed the problem of maintenance of soil fertility as a limiting factor, in addition to other aspects such as low income, reduced interest in annual cropping and area available for the continuation of itinerant farming, which revealed that there would be a shortage of demand for mechanisation in the region. The current conditions in terms of agrarian system evolution do not facilitate the transition to fixed farming or the intensification of production systems based on mechanisation. Nevertheless, the authors draw attention to the specificity of the results in function of collective interests, and the necessity of undertaking more detailed studies with farmers who were using animal traction with apparent success.

\section{Keywords}

Mechanisation - Smallholder farmers - Soil fertility - Costs of mechanisation - Animal traction. 


\section{Problemática}

O diagnóstico do Laboratório Agroecológico - LAET (Castellanet et al., no prelo) coloca a seguinte questão: com a expansão das áreas e a concentração fundiária, como vai evoluir a densidade humana na região da Transamazônica? O padrão inicial de 100 ha para o colono provoca uma baixa densidade humana (seis a oito pessoas por quilômetro quadrado) e uma produção agrícola relativamente baixa em relação a rede de estradas a ser mantida (da ordem de $10 \mathrm{t}$ de arroz por $\mathrm{km}$ de vicinal/ano). Com a concentração fundiária, a densidade populacional baixa cada vez mais, aumentando o custo dos serviços básicos e dificultando muito a vida social e econômica. Este comportamento provoca uma aceleração do êxodo rural e o crescimento de bairros periféricos das cidades vizinhas, caso do bairro Brasília em Altamira, com perspectivas de desemprego e/ou rendas baixas (Ferreira et al., 1994). Em médio prazo é todo o futuro da região que está ameaçado, porque quase toda a rede comercial e industrial local está voltada para a satisfação das necessidades dos produtores rurais.

Esse fenômeno está relacionado a uma tendência muito preocupante que é a pecuarização da produção (Veiga et al., 1995). A produção da pecuária de corte por hectare é baixa, e também não justifica a manutenção das vicinais. A tendência dos produtores de gado é desmatar todo o seu lote, acabando com a vegetação natural, ao contrário dos produtores de culturas anuais, que sempre deixam uma área em pousio depois de dois anos de cultivos. A sustentabilidade dessas grandes áreas de pasto é muito questionável, considerando os dados sobre os resultados dos primeiros programas de implantação de pastagens na Amazônia. Apesar desse fato, a abertura de vegetação provoca a extensão cada vez mais preocupante de fogos incontroláveis nas florestas vizinhas (Castellanet et al., 1997).

O fato é que na região da Transamazônica um dos cenários apontados por Hamelin (1991) é a médio prazo uma queda dos preços da terra, queda na oferta de empregos, extensificação destinada a compensar a perda da produtividade, parada da imigração e emigração dos jovens, enfim, diminuição dos investimentos sociais; e no longo prazo a criação de latifúndios pouco produtivos, degradação ecológica acentuada e abandono da região, demográfica e biologicamente transformada em deserto, provavelmente de maneira irreversível em muitos aspectos.

O quadro de resolução desta problemática aponta para um processo de intensificação dos sistemas de produção, associado a um planejamento do uso do espaço municipal. Isso tem sido objeto de um amplo debate entre organizações de produtores, pesquisadores, munici- 
palidades e órgãos territoriais, principalmente no município de Uruará, onde foram realizadas duas conferências nesse sentido e um seminário sobre colonização com vistas a repensar o modelo.

Se considera que a intensificação da agricultura passa pela introdução de tecnologias adequadas para o trabalho do solo e de adubação para as culturas anuais e pastos, juntamente com um certo planejamento e controle do uso do espaço. As contradições entre o interesse individual do produtores o interesse comum das comunidades chamam para um trabalho sobre planejamento da ocupação agrícola pelas coletividades locais, tanto no nível das organizações de produtores como no nível dos governos locais, em particular as municipalidades. Uma das pistas mais interessantes hoje consiste em analisar a produtividade e o nível de vida dos miniproprietários que vão se multiplicando nos últimos anos em torno da periferia das cidades, num processo denominado de "chacarização" observado em várias regiões. Daí advém a idéia de aglutinar mais os produtores em áreas menores mais próximas da beira da rodovia, sendo que isso possibilitaria o atendimento de serviços básicos por parte do Estado, em particular a manutenção do acesso, na medida em que nenhuma prefeitura consegue dispor de recursos suficientes para recuperar 2000 ou mais quilômetros de vicinais, e, a formação de reservas florestais para usufruto da geração futura.

Deste modo, nestas áreas menores com maior densidade humana, uma das possibilidades de aumento substancial da produtividade do trabalho nas culturas anuais, apontada pelos produtores, seria a introdução da mecanização, junto ao manejo adequado da fertilidade para intensificar a produção de grãos em áreas destocadas. Faz-se necessário, entretanto, analisar a rentabilidade econômica da mecanização, em função dos custos adicionais gerados, verificando os efeitos de um manejo mais intensivo sobre a fertilidade dos solos, antes de concluir sobre a validade dessa proposta para a região. Também é importante conhecer as experiências dos produtores a respeito dessa questão.

Nesse contexto, o presente estudo busca estabelecer referências preliminares sobre o uso da mecanização, bem como elaborar um documento para subsidiar as discussões no nível das organizações, a partir de duas pesquisas complementares entre si:

a) O acompanhamento do "Projeto de Mecanização" desenvolvido no município de Altamira, coordenado pela Secretaria Municipal de Agricultura - SEMAGRI. Esse projeto, vinculado à Prefeitura, constava de atividades que envolviam o preparo de áreas para cinqüenta agricultores, em lotes situados à "beira da rodovia"1 , através da motomecanização,

O Programa tinha também como objetivo ser uma experiência modelo, que os outros agricultores deveriam ver e copiar, isso nortearia o processo de escolha dos agricultores que fariam parte do Programa. 
sendo a destoca com trator de esteira e a gradagem com trator de pneus. Os trabalhos de riscagem das linhas de plantio, limpeza (capinas) e preparo do solo para o ciclo agrícola seguinte seriam realizados com tração animal, com o compromisso dos agricultores produzirem na mesma área, durante três anos, as culturas do arroz, milho e feijão (EMATER, 1993). O objetivo desse acompanhamento foi obter elementos para uma análise técnica-econômica da experiência que seria desenvolvida nos lotes dos agricultores, buscando discutir com eles as possibilidades de utilização ou não da mecanização na região. Nessa perspectiva, elaborou-se o protocolo de acompanhamento ${ }^{2}$ visando avaliar, do ponto de vista técnico, os efeitos de um manejo mais intensivo sobre a fertilidade do solo e rendimento das culturas, além da viabilidade em termos econômicos.

b) O levantamento das experiências existentes na região, com base sobretudo na situação de Uruará. Trata-se de um breve diagnóstico sobre o uso da motomecanização e da tração animal pelos agricultores, identificando os principais fatores positivos e limitantes na produção das culturas anuais.

\section{Conhecimento científico já disponível: hipóteses de pesquisa}

Como já discutido em Schmitz et al. (1996) a introdução da mecanização não representa simplesmente uma inovação tecnológica isolada. Ela está ligada à transição da agricultura migratória para a agricultura permanente e significa mudanças profundas no sistema de produção (Boserup, 1987; Pingali et al., 1987; Schmitz et al., 1991). Para melhor entendimento, será descrito o sistema tradicional da agricultura na Amazônia (sistema "corte e queima"), que é usado na maioria das propriedades de agricultura familiar e é caracterizado pela rotação da área cultivada dentro de uma determinada área ocupada continuamente pelo agricultor (estabelecimento agrícola). Para essa forma de agricultura migratória, caracterizada pela restrição à uma área limitada, será utilizado o termo agricultura itinerante. A bibliografia amazônica não distingue sempre entre os termos para descrever o mesmo sistema. Kitamura (1982), por exemplo, usa agricultura migratória, Flohrschütz (1983) e Walker et al. (1997) falam de agricultura itinerante.

Nesse sistema tradicional, o agricultor derruba uma floresta virgem, queima a matéria orgânica e planta nessa área ("roça"), num período de um a três anos, culturas anuais. Em seguida, a área se transfor-

\footnotetext{
Nesse protocolo contavam as seguintes atividades: coletas de amostras de solos antes e após o preparo do solo, instalação de pluviômetros para acompanhamento da chuva, registro dos itinerários técnicos e do calendário de trabalho, registro da produção obtida, dos custos e receitas.
} 
ma em capoeira alta ou com o decorrer do uso em capoeira fina ou juquira para ser usada apenas depois de um certo período. A relação entre os anos de uso da terra (A) e o tempo de pousio (B), segundo Ruthenberg (1980) é o fator de rotação (R), um indicador da intensidade do uso da terra:

$$
\mathrm{R}(\%)=\mathrm{A} /(\mathrm{A}+\mathrm{B}) * 100
$$

Nessa base os pesquisadores formularam as seguintes hipóteses:

a) Com o aumento do uso da terra, principalmente causado pelo crescimento da população, o tempo de pousio (descanso da terra) diminui (transição da agricultura itinerante para a agricultura permanente caracterizada pelo uso contínuo da área). Isto provoca uma perda de fertilidade do solo e um aumento da infestação com "ervas daninhas" (vegetação espontânea, mais adaptada ao lugar e que nem sempre prejudica a cultura plantada), tornando-se necessário mais tempo de trabalho para a produção da mesma quantidade de alimentos básicos. O sistema começa a se tornar instável a partir de uma população de 20 até 25 habitantes/km² (Spencer, 1977; Sanchez, 1977 citados por Kitamura, 1982);

b) A mecanização, nesse momento, pode ser usada como meio para contrariar a tendência à perda de rendimento do trabalho. Além disso, a mecanização, nas pequenas propriedades muitas vezes com tração animal, permite o aumento da área cultivada;

c) A introdução da mecanização ocorre em geral só a partir de um determinado nível de intensidade de uso da terra (R > $40 \%$ ), muitas vezes, ligado a um certo valor de densidade populacional (> 60 habitantes $/ \mathrm{km}^{2}$ na África, por exemplo) (Pingali et al., 1987). Esses fatores estão atualmente longe de serem alcançados na Transamazônica;

d) A mecanização, no início, é introduzida apenas para o preparo do solo e capina (além do transporte, que segue outras regras). É aplicada só em determinadas culturas, principalmente culturas anuais (como milho e feijão), e menos em culturas perenes, em que se aproveita só a capina (caso da pimentado-reino) $)^{3}$;

\footnotetext{
A principal razão para a introdução da mecanização é a perda de rendimento de trabalho devido ao aumento das "ervas daninhas". O controle dessas invasoras tem que começar já antes do plantio da cultura para garantir que as sementes possam emergir e competir com a vegetação espontânea. Esse preparo do solo é efetuado, na mecanização, com o arado. Na fase de crescimento da cultura precisa-se, em função da cobertura vegetal, de até três capinas, que podem ser realizadas com um cultivador à tração animal. Normalmente o uso do arado é o primeiro passo da mecanização, enquanto a introdução do
} 
e) O problema principal, na transição da agricultura itinerante para a agricultura permanente, é o manejo da fertilidade do solo (substituição dos nutrientes, controle do valor do pH), o qual, até neste momento, só é resolvido pela queima e o posterior pousio. O problema se agrava em solos com baixa fertilidade, correspondendo à maioria das áreas na Transamazônica. Alternativas ao método tradicional significam muita mão-de-obra (adubo orgânico) ou custos altos (adubo mineral). Outros entraves na fase inicial são a limpeza da área (destoca) e a alimentação animal;

f) Como a mecanização está ligada à transição da agricultura itinerante para a agricultura permanente, ela não pode ser introduzida a qualquer momento. O momento certo é determinado pela relação entre a quantidade de trabalho, no sistema tradicional, que está aumentando (ver a primeira hipótese) e a do trabalho necessário para poder usar a mecanização sendo, no caso da tração animal, por exemplo, o treinamento do agricultor, o adestramento dos animais, a destoca, a formação e o manejo de pastagem para os animais de serviço e o manejo dos animais. Não pode ser antecipado esse momento, senão a inovação resulta em uma perda de rendimento de trabalho ao invés de aumento;

g) O preparo do solo, na maioria dos casos, não resulta em um aumento do rendimento (produção) por área. Ao contrário, principalmente a exposição do solo descoberto à influência do tempo (chuva tropical, temperaturas altas) provoca uma perda sensível da sua fertilidade. A principal razão para o preparo do solo é a necessidade do controle da infestação, devido ao aumento das ervas daninhas causado pela diminuição do pousio. Mexer o solo, em geral, só é vantajoso se já tiver ocorrido uma alteração, como compactação por exemplo.

h) A experiência anterior do agricultor com mecanização tem um papel positivo a curto prazo, mas não é um fator decisivo.

Segundo Ruthenberg (1980), estas hipóteses valem apenas para a agricultura familiar (pequenos agricultores, camponeses). Estabeleci-

cultivador ocorre mais tarde, pois o trabalho entre as linhas das culturas requer mais habilidade do homem e do animal. Precisase, também, uma área melhor preparada e o plantio efetivado em linha para poder passar com cultivador sem maiores problemas. O plantio que normalmente, no clima tropical úmido, não apresenta um grande pique de trabalho, pode ser realizado por mais tempo com uma semeadeira manual (matraca). A semeadeira à tração animal requer mais atenção devido à necessidade de regulagem e manutenção; ela é relativamente cara e precisa de uma área relativamente limpa. O efeito de diminuição do tempo de trabalho, por exemplo comparado entre tração animal e trabalho manual, é menor no plantio que no preparo da área e na capina. A colheita continua, em geral, de forma manual por causa dos altos custos dos equipamentos em relação ao preço do produto e o tamanho das roças na agricultura familiar. Por estas razões, a mecanização, em geral, é aplicada apenas em culturas, onde precisa-se fazer, cada ano, o preparo de solo e/ou o controle de "ervas daninhas" (Schmitz et al., 1991). 
mentos maiores (fazenda, agroindústria, latifúndio) dispõem de recursos suficientes para ultrapassar etapas deste processo, com o uso do trator e adubo mineral, e realizar uma transição mais abrupta. A dinâmica do desenvolvimento dos sistemas de produção depende, assim, do tipo de estabelecimento e, especialmente, do capital disponível.

A tração animal apresenta vantagens para a agricultura familiar por causa da necessidade menor em termos de capital e por ser eficiente economicamente, também, em áreas menores, além de ser usada para o controle das ervas daninhas, que no caso da motomecanização continua muitas vezes com enxada ou exige a utilização de herbicidas. A transição da tração animal para a motomecanização não é um passo natural; ela depende, entre outros fatores, das condições do terreno (topografia, tamanho das parcelas, ocorrência de tocos) onde a lavoura será introduzida, e dos fatores econômicos do estabelecimento.

As hipóteses acima referidas sobre a dinâmica do desenvolvimento dos sistemas de produção e mecanização, até agora, não entraram na discussão sobre a introdução da mecanização no Estado do Pará. Pimentel et al. (1992) descrevem que várias tentativas de introdução da tração animal no nordeste paraense não deram o resultado esperado por falta de adoção pelos próprios agricultores, citando como razões principais pelo fracasso a falta de tradição, os custos altos dos equipamentos e a falta de informação.

Para futuras experiências nesta área, foi recomendada a inclusão, principalmente, de entidades representativas dos agricultores. De um modo geral, o fracasso dessas tentativas pode ser atribuído à falta de uma análise anterior dos sistemas de produção e de uma verdadeira participação dos agricultores que levasse à co-construção de novos conhecimentos (Martins, 1992).

Decorre desses resultados, e, conforme o conhecimento científico sobre a dinâmica da evolução dos sistemas de produção, que a maioria dos pequenos agricultores, considerando as condições da Transamazônica, com solos menos férteis, não deveria estar interessada em mecanizar.

\section{Resultados e discussões}

\section{a) O acompanhamento da experiência de mecanização em Altamira}

Foram elaboradas sínteses dos relatórios de visita, de diários de campo, dos encontros de avaliação técnica, sistematização dos questionários e das informações referentes às alterações na fertilidade do solos, pluviometria, calendário de trabalho e custos iniciais para o preparo da área. 


\section{a.1) Pontos técnicos}

A destoca com o trator de esteira provocou a retirada da camada superficial do solo em todas as áreas, provocando compactação do solo na maioria delas e formação de bacias (locais onde foi observando bastante acúmulo de água) em alguns casos. Os agricultores expressaram a seguinte opinião a esse respeito:

Agricultor: "... O projeto é bom mas deveria se ter mais cuidado com a profundidade de corte da terra, senão é mais prejuízo que vantagem...".

Agricultor: "...As máquinas chegaram atrasadas, a chuva já tava forte, aí o trabalho fica essa desgraçeira toda, a terra fica socada (compactada), o trator quebra, fica essa pauleira velha (restos de tocos, raízes, galhos, etc.) toda aí prá gente tirar, atrasa o plantio... e aí a gente nem sabe se vai produzir alguma coisa porque toda a camada preta (matéria orgânica), aquela parte de cima onde a terra é rica e o legume se desenvolve, ficou tudo amontoada ali na leira (onde o trator de esteira vai depositando, em forma de fila, o material retirado pela lâmina que pode ser contínua ou de garfo).

Os resultados da pesquisa apontam, de uma forma geral, que nos quatro estabelecimentos onde se fez coleta de solos antes e após a prática de destoca com o trator de esteira, houve um decréscimo dos teores de matéria orgânica, entre aproximadamente 4 a 30\% na terra roxa (terra roxa estruturada) e 9 a 27\% na terra mista (podzólico vermelho amarelo), confirmando assim a observação dos agricultores (Quadro 1) ${ }^{4}$ sobre a remoção da "camada preta"superficial do solo.

4 O quadro é apenas uma referência para contribuir na formalização da observação dos agricultores, por isso que os tipos de solos indicados correspondem as classificações por eles utilizadas e o parâmetro escolhido foi o teor de matéria orgânica, que mais se aproximou do discurso dos mesmos ("a camada preta, alimento da terra..."). 
Quadro 1 - Variação dos níveis de matéria orgânica, em diferentes profundidades, em dois tipos de solos, antes e após a operação de destoca mecanizada.

\begin{tabular}{|c|c|c|c|c|c|}
\hline $\begin{array}{l}\text { № do } \\
\text { lote }\end{array}$ & $\begin{array}{l}\text { Tipo de } \\
\text { Solo }\end{array}$ & $\begin{array}{l}\text { Profundidade } \\
\text { (cm) }\end{array}$ & $\begin{array}{l}\text { Antes da } \\
\text { destoca } \\
\text { M.O(\%) }\end{array}$ & $\begin{array}{c}\text { Depois da } \\
\text { destoca } \\
\text { M.O.(\%) }\end{array}$ & $\begin{array}{c}\text { Variação } \\
\text { (\%) }\end{array}$ \\
\hline & & $0-10$ & 3,4 & 2,78 & 18,2 \\
\hline 1 & Terra roxa & $\begin{array}{l}10-20 \\
20-40 \\
\end{array}$ & $\begin{array}{l}2,54 \\
1,86 \\
\end{array}$ & $\begin{array}{l}2,35 \\
1,79 \\
\end{array}$ & $\begin{array}{l}7,5 \\
3,8 \\
\end{array}$ \\
\hline 2 & Terra roxa & $\begin{array}{c}0-10 \\
10-20 \\
20-40 \\
\end{array}$ & $\begin{array}{l}3,15 \\
2,29 \\
1,55 \\
\end{array}$ & $\begin{array}{c}2,6 \\
1,61 \\
1,3 \\
\end{array}$ & $\begin{array}{l}17,5 \\
29,7 \\
16,1 \\
\end{array}$ \\
\hline 3 & Terra mista & $\begin{array}{c}0-10 \\
10-20 \\
20-40\end{array}$ & $\begin{array}{l}3,46 \\
3,13 \\
2,41 \\
\end{array}$ & $\begin{array}{c}2,6 \\
2,84 \\
1,92 \\
\end{array}$ & $\begin{array}{c}24,9 \\
9,3 \\
20,3 \\
\end{array}$ \\
\hline 4 & Terra mista & $\begin{array}{c}0,10 \\
10-20 \\
20-40\end{array}$ & $\begin{array}{l}3,09 \\
2,41 \\
1,79\end{array}$ & $\begin{array}{l}2,25 \\
1,76 \\
1,42\end{array}$ & $\begin{array}{l}27,2 \\
27,0 \\
20,7\end{array}$ \\
\hline
\end{tabular}

Fonte: Pesquisa de campo.

Uma rápida reflexão sobre o período de realização das atividades desenvolvidas no programa em relação à distribuição das chuvas, demonstra que de fato houve atraso no preparo da área de vários agricultores, sendo que parte dessas atividades foram realizadas na época chuvosa. Isso alterou também o itinerário técnico ${ }^{5}$ objetivado e realizado pelos agricultores (Quadro 2). O período previsto para destoca, aração e gradagem deveria compreender os meses de setembro a novembro, período de baixa intensidade pluviométrica.

O preparo do solo no período chuvoso pode acarretar sérios prejuízos à estrutura do solo (Derpsch et al., 1991), fato confirmado pelos agricultores que afirmaram que as operações com trator de esteira, quando o solo está muito úmido, facilita o processo de compactação (... "a terra fica socada"...), além de aumentar o tempo e os custos da operação.

Um itinerário técnico é definido como uma sucessão lógica e ordenada de técnicas aplicadas à uma cultura dada visando satisfazer os objetivos de produção (Sébillotte, 1978). Essas técnicas estão em acordo com a evolução natural do meio ambiente, incluindo particularmente as alterações provocadas por mudanças climáticas (Sébillotte, 1987). 
Quadro 2- Calendário de atividades do Programa de Mecanização e distribuição pluviométrica no município de Altamira, no período setembro/fevereiro, ciclo 93/94.

\begin{tabular}{|c|c|c|c|c|c|c|c|c|c|c|c|c|c|c|c|c|c|c|c|c|}
\hline \multirow[b]{2}{*}{ Mês } & \multirow[b]{2}{*}{ Sem. } & \multirow[b]{2}{*}{ Data } & \multicolumn{16}{|c|}{ AGRICULTORES } & \multirow[b]{2}{*}{$\begin{array}{c}\text { Chuva } \\
\text { (mm) }\end{array}$} & \multirow[b]{2}{*}{$\begin{array}{c}\text { Total } \\
\mathrm{mm} / \mathrm{m}\end{array}$} \\
\hline & & & 1 & 2 & 3 & 4 & 5 & 6 & 7 & 8 & 9 & 10 & 11 & 12 & 13 & 14 & 15 & 16 & & \\
\hline \multirow[t]{5}{*}{ Set } & $1^{\mathrm{a}^{\mathrm{a}}}$ & $8-12 / 9$ & & & & & & & & & & & & & & & & & 10,50 & \\
\hline & $2^{\mathrm{a}}$ & $13-17 / 9$ & & & & & & & & & & & & & & & & & 1,80 & \\
\hline & $3^{a}$ & $18-22 / 9$ & & & & & & & & & & & & & & & & & 1,00 & 24,10 \\
\hline & $4^{\frac{a}{a}}$ & $23-27 / 9$ & & & & & & & & & & & & & & & & & 8,30 & \\
\hline & $5^{a}$ & $28-2 / 10$ & & & & & & & & & & & & & & & & & 2,50 & \\
\hline \multirow[t]{9}{*}{ Out } & $6^{a}$ & $3-7 / 10$ & & & & & & & & & & & & & & & & & 0,00 & \\
\hline & $7^{\mathrm{a}}$ & $8.12 / 10$ & & & & & & & & & & & & & & & & & 4,00 & \\
\hline & $8^{\mathrm{a}}$ & 13- & & & & & & & & & & & & & & & & & 4,00 & 31,00 \\
\hline & & $17 / 10$ & & & & & & & & & & & & & & & & & & \\
\hline & $9^{\mathrm{a}}$ & $18-$ & & & & & & & & & & & & & & & & & 6,50 & \\
\hline & & $22 / 10$ & & & & & & & & & & & & & & & & & & \\
\hline & $10^{\mathrm{a}}$ & $23-$ & & & D & & & & & $\mathbb{Z}$ & & & & & & & & & 0,50 & \\
\hline & & $27 / 10$ & & & & & & & & III & & & & & & & & & & \\
\hline & $11^{\underline{a}}$ & $28-1 / 11$ & & & & & D & & & & & & & & & & & & 16,00 & \\
\hline \multirow[t]{11}{*}{ Nov } & $12^{\mathrm{a}}$ & $2-6 / 11$ & D & & 6 & & $G$ & D & & & & & & & & & & & 3,00 & \\
\hline & & & & & ma & & $\overline{\mathbb{Z}}$ & & & & & & & & & & & & & \\
\hline & $13^{\mathrm{a}}$ & $7-11 / 11$ & & D & & & 魚 & 6 & & & & & & & & & & & 20,50 & \\
\hline & & & & & & & 奋 & m & & & & & & & & & & & & \\
\hline & $14^{\mathrm{a}}$ & $12-$ & 6 & & 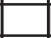 & D & & 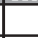 & & & & & & & & & & & 40,50 & 118,30 \\
\hline & & $16 / 11$ & & & & & & & & & & & & & & & & & & \\
\hline & $15^{\mathrm{a}}$ & $17-$ & & & & & $P$ & 吾 & & & $\mathbb{Z}$ & & & & & & & & 36,00 & \\
\hline & & $21 / 11$ & & & & & & $\overline{\mathbf{R}}$ & & & III & & & & & & & & & \\
\hline & $16^{\frac{a}{a}}$ & $22-$ & & & & & & $\mathbf{P}$ & $\mathbf{R}$ & & & m & & 2 & & & & & 11,00 & \\
\hline & & $26 / 11$ & & & & & & & & & & man & & III & & & & & & \\
\hline & $17^{\underline{a}}$ & $27-1 / 12$ & & & & $G$ & & 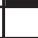 & $\mathbf{P}$ & & 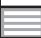 & 堽 & $\mathbb{Z}$ & 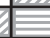 & & & & & 7,30 & \\
\hline \multirow[t]{10}{*}{ Dez } & $18^{\frac{a}{2}}$ & $2-6 / 12$ & & $G$ & & & & & & & & & 立 & & & & & & 9,00 & \\
\hline & $19^{\mathrm{a}}$ & $7-11 / 12$ & & & & & & & & & & & & & & & & & 3,50 & \\
\hline & $20^{\mathrm{a}}$ & $12-$ & & & RRA & 青 & & 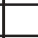 & & & & & & & & & & & 5,60 & 171,10 \\
\hline & & $16 / 12$ & & & & 垔 & & & & & & & & & & & & & & \\
\hline & $21^{\mathrm{a}}$ & $17-$ & & RR & $\mathbf{P}$ & $P$ & & 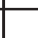 & & & & & & & & & & & 25,30 & \\
\hline & & $21 / 12$ & & & & & & & & & & & & & & & & & & \\
\hline & $22^{a}$ & $22-$ & & $\mathbf{P}$ & 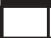 & & & 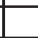 & & & & & & & & & & & 60,00 & \\
\hline & & $26 / 12$ & & & & & & & & & & & & & & & & & & \\
\hline & $23^{a}$ & $27-$ & & & & & & 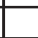 & & & & & & & & & & $\mathbb{Z}$ & 67,70 & \\
\hline & & $31 / 12$ & & & & & & & & & & & & & & & & III & & \\
\hline \multirow[t]{8}{*}{ Jan } & $24^{\frac{a}{a}}$ & $1-5 / 1$ & & & & & & & & & & & & & III & III & The & m. & 34,30 & \\
\hline & $25^{\mathrm{a}}$ & $6-10 / 1$ & RRA & & & & & & & & & & & & & & & & 37,00 & \\
\hline & $26^{\mathrm{a}}$ & $11-15 / 1$ & P & & & & & & & & & & & & & & & & 4,70 & 164,10 \\
\hline & $27^{\mathrm{a}}$ & $16-20 / 1$ & & & & & & & & & & & & & & & & 旦 & 50,80 & \\
\hline & $28^{\mathrm{a}}$ & $21-$ & & & & & & & & & & & & & 晅 & & 些 & & 32,30 & \\
\hline & & $25 / 1$ & & & & & & & & & & & & & 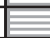 & & 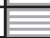 & & & \\
\hline & $29^{\mathrm{a}}$ & $26-$ & & & & & & & & & & & & & & & & & 5,00 & \\
\hline & & $30 / 1$ & & & & & & & & & & & & & & & & & & \\
\hline \multirow[t]{9}{*}{ Fev } & $30^{\mathrm{a}}$ & $31-4 / 2$ & & & & & & & & & & & & & & & & & 56,50 & \\
\hline & $31^{\mathrm{a}}$ & $5-9 / 2$ & & & & & & & & & & & & & & & & & 62,50 & \\
\hline & $32^{\mathrm{a}}$ & 10 & & & & & & & & & & & & & & & & & 27,30 & 261,30 \\
\hline & & $14 / 2$ & & & & & & & & & & & & & & & & & & \\
\hline & $33^{\mathrm{a}}$ & 15- & & & & & & & & & & & & & & & & & 40,00 & \\
\hline & & $19 / 2$ & & & & & & & & & & & & & & & & & & \\
\hline & $34^{\mathrm{a}}$ & $20-$ & & & & & & & & & & & & & & & & & 39,00 & \\
\hline & & $24 / 2$ & & & & & & & & & & & & & & & & & & \\
\hline & $35^{\mathrm{a}}$ & $25-1 / 3$ & & & & & & & & & & & & & & & & & 36,00 & \\
\hline
\end{tabular}

Fonte: Pesquisa de campo

Legenda: Destoca $\equiv$ Retirada dos restos ש Gradagem $\square$ Plantio de arroz e milho 
Os dados do quadro 2 mostram que nas áreas de 04 agricultores a gradagem foi realizada no fim do mês de janeiro, sendo que dois agricultores plantaram o arroz e milho somente no início de fevereiro. Além do aumento dos custos no preparo da área esses agricultores tiveram que aplicar mais força de trabalho na prática da capina, que é mais trabalhosa com o solo úmido e pesado, além do agravante da vegetação secundária desenvolver-se mais rapidamente nessas condições.

Verificou-se que a tração animal foi utilizada apenas no início para a riscagem da linhas de plantio (na maioria dos casos) e para capina de apenas uma parte das roças de milho, com o apoio total dos técnicos da SEMAGRI e da Escola Agrícola de Altamira. Uma parte porque a capina com tração animal só é viável quando as invasoras estão na sua fase inicial de desenvolvimento. Como as capinadeiras (cultivadores 5 enxadas cedidos pela SEMAGRI) chegaram tarde, não foi possível proceder essa prática no momento certo. É importante também considerar a distribuição de chuvas nos meses de janeiro e fevereiro, pois como o solo estava muito úmido durante esse período e o mato já desenvolvido, houve "embuchamento" nas enxadas dos cultivadores, impossibilitando a operação.

No caso da cultura do arroz todo o trabalho de capina procedeu de forma manual com enxada, isso porque apesar dos agricultores terem plantado em linha, utilizaram um espaçamento mais adensado, não permitindo assim o trabalho com o tipo de equipamento de tração animal fornecido pela SEMAGRI. Isso demonstra a importância de conhecer a práticas dos agricultores antes de se implementar um proposta de mudança técnica, desde que o diálogo entre pesquisadores, técnicos e agricultores pode contribuir para reformar e/ou aperfeiçoar essas práticas (Darré, 1996).

Observou-se bastante desuniformidade no desenvolvimento vegetativo das culturas, principalmente do milho. Os agricultores atribuíram esse fato à má qualidade da semente distribuída pela SEMAGRI. Porém, os agrônomos-pesquisadores argumentaram sobre a importância de considerar outros aspectos como antecedentes das áreas, estado nutricional do solo e as diferentes datas de plantio. Esses fatores foram bastante úteis nas discussões "in situ" com os agricultores sobre as diferenças encontradas entre as parcelas cultivadas.

Alguns agricultores se empenharam em mostrar as desigualdades dentro da mesma parcela cultivada, comparando o estado de desenvolvimento vegetativo das plantas próximas ou em cima das leiras queimadas com as que estavam plantadas em linhas, segundo o padrão técnico recomendado (adotado com exceção da prática de adubação que 
não foi seguida pela maioria dos agricultores). Eles queriam mostrar que onde havia sido queimado ou tinha rastros de cinzas, as plantas apresentavam-se bem mais vigorosas. Um deles argumentou: "...o pessoal que derrubou, queimou e botou roça tá com elas bem melhor do que as nossas, esse milho parece que nem vai embonecar (produzir espiga),...parece que para produzir bem o negócio é queimar mesmo...".

A cultura do arroz também apresentou sérios problemas de desenvolvimento na metade dos casos. Isso foi devido ao forte ataque da cigarrinha das pastagens, pois as áreas desses agricultores eram pastos recuperados, ou ainda, se situavam ao lado das áreas de pastagens.

Importante anotar: nesse momento, em que se vivenciava a experiência, os agricultores tinham a possibilidade de descobrir os riscos associados ao trabalho de mecanização e introduzir questões sobre as implicações decorrentes das mudanças técnicas no sistema de produção.

a. 2) Os custos iniciais do preparo da área e as questões econômicas.

Os primeiros resultados demonstraram que o custo inicial para o preparo mecanizado da área era em média $\mathrm{R} \$ 400,00 /$ ha por agricultor (Quadro 3), considerando o valor da hora do trator de esteira equivalente a $\mathrm{R} \$ 55,00$, o custo/hora do trator de pneus a $\mathrm{R} \$ 18,00$ e a diária de um trabalhador igual a $\mathrm{R} \$ 5,00$, valores esses que vigoravam na época (ano agrícola 1993-1994).

Caso esses custos fossem cobrados em equivalência-produto seria necessário atingir em média um rendimento de $1.500 \mathrm{~kg} / \mathrm{ha}$ para o arroz (equivalente a 25 sacos/ha), ou $1.366 \mathrm{~kg} / \mathrm{ha}$ de milho (igual a 23 sacos/ha), ou ainda $600 \mathrm{~kg} / \mathrm{ha}$ de feijão (igual a 10 sacos/ha), para remunerar os custos iniciais (Quadro 4). Considerando os preços de venda alcançado pelos produtores: $\mathrm{R} \$ 16,00 ; \mathrm{R} \$ 17,5$ e $\mathrm{R} \$ 40,00$ para o saco (60 kg) de arroz, milho e feijão, respectivamente. Preços muito bons naquela ocasião. 
Quadro 3 - Custos iniciais do Projeto de Mecanização em Altamira para o preparo de área mecanizado

\begin{tabular}{|c|c|c|c|c|c|c|}
\hline Cód. & $\begin{array}{c}\text { Área } \\
(\mathbf{H a})\end{array}$ & $\begin{array}{c}\text { Tempo de } \\
\text { Destoca }(\mathrm{h})\end{array}$ & $\begin{array}{c}\text { Retirada } \\
\text { Dos restos }(\mathbf{h} / \mathbf{d})\end{array}$ & $\begin{array}{c}\text { Tempo de } \\
\text { Gradagem }(\mathrm{h})\end{array}$ & $\begin{array}{c}\text { Custo } \\
\text { Total(R\$) }\end{array}$ & $\begin{array}{c}\text { Custo/ha } \\
(\mathbf{R} \$)\end{array}$ \\
\hline 1 & 5 & 12 & 50 & 18 & 1.234 & 246,8 \\
\hline 2 & 1 & 2,5 & 8 & 4 & 249,5 & 249,5 \\
\hline 3 & 4 & 8 & 30 & 20 & 950 & 237,5 \\
\hline 4 & 5 & 24 & 45 & 48 & 2.409 & 481,8 \\
\hline 5 & 4 & 9 & 25 & 8 & 764 & 191 \\
\hline 6 & 3 & 12 & 45 & 24 & 1.317 & 439 \\
\hline 7 & 5 & 24 & 30 & 36 & 2.118 & 423,6 \\
\hline 8 & 3 & 13 & 18 & 14 & 1.057 & 352,33 \\
\hline 9 & 3 & 30 & 20 & 20 & 2.110 & 703,33 \\
\hline 10 & 3 & 24 & 15 & 15 & 1.665 & 555 \\
\hline 11 & 4,5 & 16 & 25 & 16 & 1.293 & 287,33 \\
\hline 12 & 10 & 42 & 35 & 60 & 3.565 & 356,5 \\
\hline 13 & 2,5 & 24 & 35 & 15 & 1.765 & 706 \\
\hline 14 & 5 & 25 & 45 & 25 & 2.050 & 410 \\
\hline 15 & 3 & 15 & 30 & 15 & 1.245 & 415 \\
\hline 16 & 5 & 18 & 30 & 25 & 1.590 & 318 \\
\hline Totais & 66 & 298,5 & 486 & 363 & $25.381,5$ & $6.372,7$ \\
\hline Média & 4,13 & 18,7 & 30,4 & 22,7 & $1.586,34$ & 398,29 \\
\hline
\end{tabular}

Fonte: Pesquisa de Campo

O cálculo foi feito apenas com base no preparo da área, não sendo adicionados custos eventuais com insumos (sementes, fertilizantes, agrotóxicos, etc.), mão-de-obra na capina, colheita e com equipamentos de tração animal (apesar do investimento ser depreciado), nem foram consideradas as necessidades de consumo das famílias, o que requer o armazenamento de uma certa quantidade desses produtos. O que significa que para remunerar todos os custos de produção e ainda atender as necessidades de consumo os agricultores deveriam obter rendimentos superiores aos que são indicados no quadro 4. Havia a possibilidade de obtenção de sucesso econômico para alguns (os que se situaram em termos de custos bem abaixo da média) mas outros teriam prejuízo no primeiro ano (os que necessitavam obter rendimentos acima da média), ficando endividados com a prefeitura, caso eles de fato tivessem que proceder o pagamento, conforme estava previsto anteriormente.

Alguns agricultores, se tivessem que cobrir os custos iniciais de preparo da área, teriam que obter já no primeiro ano um rendimento 
superior a $1500 \mathrm{~kg} / \mathrm{ha}$ para o arroz e/ou milho, havendo situações em que esse rendimento deveria superar a marca dos $2000 \mathrm{~kg} / \mathrm{ha}$ (Quadro 4). Vários trabalhos de pesquisas realizados na região (Castellanet et al., no prelo) ${ }^{6}$ mostram que nas reais condições dos agricultores dificilmente esses rendimentos são alcançados.

E se o projeto fosse coletivo, conforme sugeria alguns presidentes de cooperativas e associações? Essa pergunta levou a uma reflexão global sobre o projeto de Altamira realizando o exercício hipotético de considerar o projeto como algo coletivo e coordenado por uma associação.

A prefeitura planejou atender 50 agricultores, mas conseguiu apenas realizar o trabalho com 22 agricultores $^{7}$ utilizando 2 tratores de esteira, 2 tratores de pneus e 15 cultivadores. Suposemos, com base nisso, que uma associação dispondo de 1 trator de esteira (que provavelmente teria que ser alugado) e 1 trator de pneu, atenderia apenas a metade dos agricultores.

Com o pressuposto de um bom planejamento e de que os 16 agricultores acompanhados na pesquisa fossem atendidos, quais seriam os resultados econômicos da experiência coletiva?

Os dados indicaram que a soma da produto bruto total, alcançado em 66 ha mecanizados - dos quais $85 \%$ eram solos de terra roxa -, foi de $\mathrm{R} \$ 41.210,00$, o que proporcionou um produto bruto de $\mathrm{R} \$ 624,40 / \mathrm{ha}$. Por outro lado, os custos do preparo das áreas totalizaram $\mathrm{R} \$ 25.381,50$, sendo equivalente a aproximadamente $\mathrm{R} \$ 385,00 / \mathrm{ha}$. Assim, a receita líquida por hectare, considerando a diferença entre a produto bruto e os custos do preparo inicial, seria de R\$ 240,00 (Quadro 5).

Esse valor não seria suficiente para remunerar em conjunto os demais custos de produção como depreciação dos cultivadores, mão-deobra, insumos, deslocamentos do trator de uma propriedade para outra, etc.. Caso as associações quisessem realizar a experiência em solos mais fracos, na terras mistas por exemplo, elas teriam que organizar um bom planejamento e avaliar cuidadosamente as vantagens e desvantagens da mecanização em termos econômicos, pois dificilmente seria evitado o aumento dos custos com a adubação química.

\footnotetext{
Cf. também os relatórios de pesquisa dos estudantes do Curso de Especialização em Agriculturas Familiares Amazônicas e Desenvolvimento Sustentável - DAZ.

Dos quais 16 foram acompanhados de perto pela equipe de pesquisa.
} 
Quadro 4 - Rendimentos necessários, das culturas de arroz, milho e feijão, para remunerar os custos iniciais com o preparo mecanizado da área

\begin{tabular}{|c|c|c|c|c|c|c|c|}
\hline Cód. & $\begin{array}{c}\text { Área } \\
\text { (ha) }\end{array}$ & $\begin{array}{c}\text { Custo/ha } \\
\text { arroz (sc) }\end{array}$ & $\begin{array}{c}\text { Rend. } \\
\mathrm{Kg} / \mathrm{ha}\end{array}$ & $\begin{array}{c}\text { Custo/ha } \\
\text { milho (sc) }\end{array}$ & $\begin{array}{c}\text { Rend. } \\
\mathrm{Kg} / \mathrm{ha}\end{array}$ & $\begin{array}{c}\text { Custo/ha } \\
\text { Feijão (sc) }\end{array}$ & $\begin{array}{c}\text { Rend. } \\
\mathrm{Kg} / \mathrm{ha}\end{array}$ \\
\hline 1 & 5 & 15 & 926 & 14 & 846 & 6 & 370 \\
\hline 2 & 1 & 16 & 936 & 14 & 855 & 6 & 374 \\
\hline 3 & 4 & 15 & 891 & 14 & 814 & 6 & 356 \\
\hline 4 & 5 & 30 & 1.807 & 28 & 1.652 & 12 & 723 \\
\hline 5 & 4 & 12 & 716 & 11 & 655 & 5 & 287 \\
\hline 6 & 3 & 27 & 1.646 & 25 & 1.505 & 11 & 659 \\
\hline 7 & 5 & 26 & 1.589 & 24 & 1.452 & 11 & 635 \\
\hline 8 & 3 & 22 & 1.321 & 20 & 1.208 & 9 & 529 \\
\hline 9 & 3 & 44 & 2.638 & 40 & 2.411 & 18 & 1.055 \\
\hline 10 & 3 & 35 & 2.081 & 32 & 1.903 & 14 & 833 \\
\hline 11 & 4,5 & 18 & 1.078 & 16 & 985 & 7 & 431 \\
\hline 12 & 10 & 22 & 1.337 & 20 & 1.222 & 9 & 535 \\
\hline 13 & 2,5 & 44 & 2.648 & 40 & 2.421 & 18 & 1.059 \\
\hline 14 & 5 & 26 & 1.538 & 23 & 1.406 & 10 & 615 \\
\hline 15 & 3 & 26 & 1.556 & 24 & 1.423 & 10 & 623 \\
\hline 16 & 5 & 20 & 1.193 & 18 & 1.090 & 8 & 477 \\
\hline Totais & 66 & 398 & & 364 & & 159 & \\
\hline Média & 4,13 & 25 & 1.494 & 23 & 1.366 & 10 & 597 \\
\hline
\end{tabular}

Fonte: Pesquisa de campo

Quadro 5 - Custos do preparo da área e receitas globais do Programa de Mecanização em Altamira.

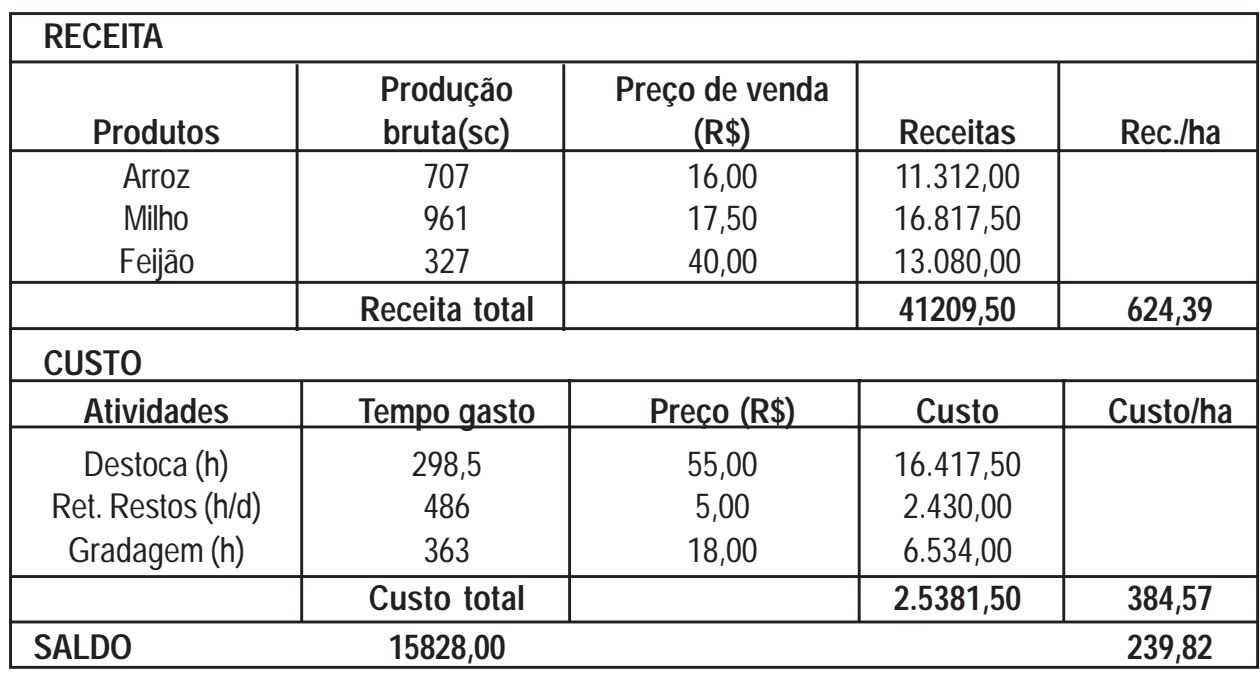

Fonte: Pesquisa de campo 


\section{b) O levantamento das experiências dos agricultores em Uruará8}

Esse levantamento indicou que poucos agricultores experimentaram a mecanização na região. Dos cerca de 3.000 agricultores em Uruará, as organizações locais identificaram apenas 9 agricultores $(0,3 \%)$.

A adoção da prática de mecanização motorizada e tração animal por esses agricultores, conduziu a vários questionamentos, ressaltando diversos fatores:

\section{b.1) Tradição, experiência e relação com novas tecnologias}

Os agricultores entrevistados sempre trabalharam na agricultura, com exceção de um deles que já tinha desenvolvido atividades no meio urbano. Todos responderam que gostavam de fazer inovações na propriedade, declarando que sempre são "os primeiros a introduzir uma nova tecnologia".

Comumente, as causas atribuídas para a não apropriação de uma determinada tecnologia focalizam também o aspecto cultural, e, no caso particular da mecanização com tração animal tem sido enfatizada, por várias vezes, a falta de tradição dos agricultores. No entanto nessa pesquisa todos os entrevistados eram provenientes das regiões Sul (a maioria) e Sudeste com experiências anteriores em preparo de solo mecanizado, sendo que alguns possuíam trator e equipamentos de tração animal, levando a constatar que no caso da Transamazônica a problemática não se assenta na questão da tradição ou do saber-fazer dos agricultores.

Ao contrário, foi observado que esses agricultores entraram num processo de aquisição de novos conhecimentos, ao adotar processos técnicos não presentes no local de origem, como é o caso da técnica de plantio de feijão abafado, desenvolvida tipicamente por nordestinos. Na verdade, alguns chegaram a experimentar a mecanização na Transamazônica, mas abandonaram-na logo depois, voltando para o sistema corte e queima.

\section{b.2) Atividades, uso da terra e tendências}

A economia dos agricultores baseava-se nas culturas perenes (em 6 estabelecimentos era a atividade mais importante). A pecuária ocupava o segundo lugar (em 3 estabelecimentos tinha maior importância entre as atividades agrícolas) e outras atividades não agrícolas eram predominantes na formação da renda de 2 estabelecimentos. As culturas anuais tinham um papel menos importante, atendendo apenas o consumo familiar.

Os resultados desse levantamentojá foram apresentados em relatório de pesquisa (Schmitz e Simões, 1994) e como contribuição ao II Encontro da Sociedade Brasileira de Sistemas de Produção, realizado em Londrina -PR, no período de 21-23/11/1995. 
Os agricultores aproveitavam 60 ha para o cultivo. Da área total do estabelecimento agrícola (média 317,5 ha entre os agricultores pesquisados) eles utilizavam em torno de 19\%. A área de pastagem com 38 ha, em média, era predominante. As culturas permanentes atingiam uma média de 16,3 ha, enquanto a área de lavoura branca (culturas temporárias), ocupava somente 5,5 ha em média. A área em pousio (capoeira, juquira), era pouco mais de duas vezes maior que a área das culturas anuais. A área era de 245 ha em média (Quadro 6) ${ }^{9}$, demonstrando que os agricultores tinham área suficiente para continuarem com o sistema de derruba e queima.

Quadro 6 - Distribuição da cobertura vegetal nos lotes dos agricultores, valores médios.

\begin{tabular}{|c|c|c|c|c|c|c|c|}
\hline & $\begin{array}{c}\text { Área } \\
\text { Total }\end{array}$ & $\begin{array}{c}\text { Culturas } \\
\text { perenes }\end{array}$ & $\begin{array}{c}\text { Culturas } \\
\text { anuais }\end{array}$ & Pastagem & $\begin{array}{c}\text { Capoeira } \\
\text { e juquira }\end{array}$ & Floresta & $\begin{array}{c}\text { Área em } \\
\text { uso }\end{array}$ \\
\hline Área (ha) & 317,5 & 16,3 & 5,6 & 38,0 & 12,6 & 245 & 60 \\
\hline Uso da terra & $100 \%$ & $5,1 \%$ & $1,7 \%$ & $12,0 \%$ & $4 \%$ & $77,2 \%$ & $18,8 \%$ \\
\hline
\end{tabular}

Fonte: Schmitz e Simões (1994)

Os planos dos agricultores para o futuro indicavam como tendência maior a expansão da pecuária com 5 respostas, sendo que as culturas permanentes apareciam em segundo lugar com 4 respostas (Quadro 7). Esse fato também é confirmado em outras pesquisas (Castellanet et al., no prelo; Veiga et al., 1995; Walker et al., 1997; Simões, 1997).

Quadro 7 - Tendência dos agricultores à modificação da estrutura do sistema de produção

\begin{tabular}{|c|c|c|c|c|c|}
\hline Tendência & $\begin{array}{c}\text { Culturas } \\
\text { perenes }\end{array}$ & $\begin{array}{c}\text { Culturas } \\
\text { anuais }\end{array}$ & Pastagem & $\begin{array}{c}\text { Criações } \\
\text { peq. animais }\end{array}$ & Floresta \\
\hline Manter & 2 & 3 & 2 & 4 & \\
\hline Expandir & 4 & 2 & 5 & 1 & 3 \\
\hline Diminuir & 1 & 1 & & & 3 \\
\hline
\end{tabular}

Fonte: Schmitz e Simões (1994)

Apesar dos dados serem expressos em valores médios não se busca com isso uma representatividade estatística, considerando que é uma "amostra intencional". Segundo Thiollent (1994:62) "(...) trata-se de um pequeno número de pessoas que são escolhidas intencionalmente em função da relevância que elas apresentam em relação a um determinado assunto. (...) Pessoas ou grupos são escolhidos em função de sua representatividade social dentro da situação considerada". 
Dois agricultores pretendiam aumentar a área de cultivos anuais. Em um caso o objetivo era garantir a produção de alimentos para as famílias que trabalhavam juntas nessa propriedade. No segundo caso, o agricultor pretendia plantar soja e arroz para a comercialização.

Esse agricultor tinha um trator e queria usá-lo para o preparo da área, mas não podia porque ainda ia tentar conseguir uma grade de disco emprestada. Também pretendia usar a tração animal para a capina, porém faltava-lhe o cultivador (capinadeira). No caso desse agricultor a idéia da mecanização era reforçada pela dificuldade de conseguir contratar mão-de-obra.

Um agricultor queria abandonar a produção de culturas anuais depois de uma tentativa frustrada de produção mecanizada para o mercado. Ele concluiu que "o preço do produto não compensa o investimento feito".

\section{b.3) Mão-de-obra e rendimentos}

Os agricultores não trabalhavam só com mão-de-obra familiar, em média 4,2 ativos, mas também com meeiros (em mais ou menos 15 \% da área em uso), diaristas e empreiteiros. As atividades que consumiam mais mão-de-obra eram a colheita da pimenta, do cacau e do arroz. Essas atividades em geral, na região Norte, não apresentam nenhuma relação direta com a mecanização.

Outro fato preponderante identificado é que a mecanização com máquinas e/ou tração animal por si só não proporcionam aumento nos rendimentos das culturas por unidade de área. Na verdade pode-se aumentar a produção global pelo aumento da área cultivada, ou ainda melhorar a eficiência do do trabalho e diminuir o grau de penosidade (Schmitz et al., 1991). Este último aspecto interessa sobremaneira aos agricultores, considerando que eles definem o grau de autoexploração de sua força de trabalho (Chayanov, 1974).

\section{b.4) Manejo de fertilidade, derrubada e destoca}

A fertilidade do solo relacionada ao tipo de manejo foi o principal fator apontado pelos agricultores. Em particular, as argumentações sobre a perda da fertilidade do solo a definir seus rumos tecnológicos. Quando da utilização da mecanização para preparo das áreas e/ou realização de tratos culturais, estão ligadas à degradação da matéria orgânica e à pobreza química dos solos da região.

Nesse caso, as pistas fornecidas pelos agricultores apontaram para o manejo/gestão da matéria orgânica através do manejo das capoeiras, e para a adoção de práticas de correção - adubação química e orgânica do solo. 
No sistema tradicional, a floresta ou a capoeira é utilizada como fonte de adubo mineral obtido através da queimada, objetivando a correção da acidez do solo pela adição de bases trocáveis. Dos 9 agricultores pelo menos 7 derrubaram mais que uma área nos últimos 7 anos, num total de 11 áreas derrubadas com uma média de 10 ha por área derrubada. Em 9 casos a queima foi efetivada após a derrubada e em somente 2 casos não foi queimado porque a destoca ocorreu imediatamente depois da derruba.

Na fase de transição da agricultura tradicional (sistema derruba queima) para a agricultura permanente os agricultores fazem um grande esforço para a limpeza da área, especialmente no caso da mecanização. Das 11 áreas derrubadas 5 áreas sofreram um processo de destoca em pelo menos 6 ha dos 10 ha derrubados, em média, por área.

Os custos para a destoca são altos. Calculou-se nessa pesquisa o valor de $\mathrm{R} \$ 255,00$ (custos do trator de esteira), mais $\mathrm{R} \$ 27,00$ para a broca, derrubada (aluguel de motoserra, que a maioria dos agricultores entrevistados tinham) e a coivara. Chegou-se a um valor de $\mathrm{R} \$ 282,00$, sendo 90\% dos custos referentes ao aluguel da máquina. Esse valor poderia variar bastante porque dependia muito do acesso ao trator de esteira (distância, disponibilidade, projeto subsidiado...).

Apesar desses custos altos, o uso da área destocada não reflete bem esse investimento. Entre as áreas dos 5 agricultores que destocaram havia uma que se tornou capoeira novamente; duas áreas estavam cobertas por pastagens. Apenas uma área de 2 ha estava sendo usada para culturas anuais e uma área de 2 ha estava plantada com pimentado-reino.

A destoca com trator de esteira evita a queima, mas provoca um arrasto da camada superficial do solo, onde se concentra a maior parte do aporte de matéria orgânica, ocorrendo uma falta de nutrientes, especialmente o nitrogênio e fósforo, no início do período do cultivo. Seria necessário desse modo uma correção inicial do pH do solo e adubação química para suprir as necessidades dos nutrientes que teoricamente seriam colocados à disposição das culturas por ocasião da queima da capoeira. Considerando também os custos altos dos adubos vale a pena buscar-se outros métodos alternativos. Alguns métodos encontravamse na prática dos próprios agricultores.

Alguns estabelecimentos possuíam áreas com poucos tocos. Porém, o processo de transformação foi diferente (destoca natural). Não foi executada uma destoca mecânica. A destoca pode ser mecânica, com trator de esteira ou de pneus, ou ainda pode ser natural.

Pode-se utilizar uma área de capoeira para fazer-se o trabalho com tração animal sem necessariamente destocá-la com trator (de rodas ou 
de esteira). Isso sugere um processo denominado de "amansar a terra" que consiste em deixar os tocos e raízes apodrecerem dentro da vegetação secundária, sendo que no terceiro retorno a essa área já seria possível utilizar a tração animal, pois o equipamento pode ser manejado de modo que os tocos maiores sejam desviados. O tempo de pousio dependerá do tipo de solo.

Na destoca natural, a área após a derruba e queima da mata é cultivada por mais ou menos 3 anos, com descanso de 1 ano e posterior queima da capoeira fina. Esse processo possibilita a decomposição dos tocos deixados depois da derruba da mata, pois a medida que o tempo passa, e esses são submetidos a várias queimas, a tendência é apodrecerem sobre o solo, permitindo a entrada da tração animal ou o uso do trator de pneus com grade de disco.

A partir do $3^{\circ}$ ano o uso da tração animal para o preparo do solo e capina é possível, como confirmaram a maioria dos agricultores entrevistados, usando com preferência implementos rústicos que foram usados no sul do Brasil em áreas recém desbravadas. No decorrer do tempo os tocos podem ser retirados com uso de força manual ou animal.

Alguns agricultores indicaram ser a capoeira aproveitável sem a prática da queimada, pelos que possuem trator e grade. Nesse caso os pousios seriam curtos, a capoeira fina seria cortada e deixada para apodrecer sobre o solo e mais tarde incorporada com a gradagem. Essa prática poderia manter estável a taxa de matéria orgânica bem como melhorar a estrutura do solo (Denich, 1991).

A maioria dos agricultores (5) usava o pousio de curto tempo para o manejo de fertilidade. O fator de rotação era igual a 50\% ( $R=50 \%)$. Isso significa que os anos de uso eram iguais aos anos de descanso. O tempo de descanso na média era de 2,5 anos. Dois (2) agricultores não revelaram como eles faziam o manejo de fertilidade, sendo que um só produzia cacau. Apenas um agricultor usou fertilizantes (na cultura do milho), 3 agricultores nunca usaram fertilizantes. A maioria (5) opinaram que o uso de fertilizantes não está remunerado pela produção. Ninguém havia feito uma correção e adubação inicial depois da destoca sem queima.

Sobre a correção da acidez e adubação de reposição era bem claro para os agricultores que a mecanização na região pressupunha a adoção da prática de calagem (correção do solo), pois com a inexistência da queima não haveria a adição de bases trocáveis no solo. A redução da fertilidade do solo era inevitável e a adubação química, em particular na base de fósforo, seria indispensável. Esse aspecto era mais agravante para os agricultores que estão assentados sobre solos menos férteis como 
as "terras mistas" (latossolos e podzólicos distróficos) do que para os agricultores que possuíam solos de terra roxa estruturada e podzólicos eutróficos.

Durante as entrevistas alguns agricultores apontaram para o manejo rotativo com culturas e pastagens. Isso pode ser de fato uma opção, considerando que já foi observado, em várias circunstâncias (Cerri et al., 1991; Eden et al., 1991), que os pastos podem manter, ou talvez reconstituir, o nível de matéria orgânica (da qual a fertilidade dos solos tropicais é muito dependente) devido a seu sistema de raízes abundantes e a cobertura permanente do solo. Parece muito provável que pastos mais produtivos contribuirão para mais matéria orgânica. O uso, dentro de uma rotação de culturas mecanizadas, de pasto temporário de 4 ou 5 anos, poderia nesse caso recuperar a fertilidade orgânica e contribuir à sustentabilidade do sistema.

Os agricultores acrescentaram também que esse sistema poderia ser combinado com o uso de capoeiras de cinco anos (mais grossa), dada a produção de biomassa e formação de "litter" que após a queima podem deixar nutrientes importantes no solo, evitando-se a correção e adubação de reposição. Assim, um dos sistemas de sucessão cultural indicados para melhor gestão da fertilidade seria: mata à roça à pasto à roça à capoeira à roça. Sendo que as duas primeiras roças seriam de 2 anos e as outras subseqüentes de apenas 1 ano.

O uso de leguminosas para adubação verde também foi sugerido como alternativa, sendo questionado a viabilidade desta prática no período de estiagem. Os agricultores duvidaram que as leguminosas resistissem nos períodos de altas temperaturas e insolação mais intensa. Também questionaram as formas de incorporação no solo, caso não fosse possível dispor da mecanização.

Quanto ao uso do esterco, para reposição de matéria orgânica, foram encontrados 2 agricultores adotando esta prática no pimental, sendo que um usava também palha de cana. Os agricultores não tinham a prática de prender o gado à noite no curral, com exceção de algumas vacas leiteiras. Essa prática era adotada apenas quando eles pretendiam realizar o controle de sanidade do rebanho. Somente em 2 casos os animais ficavam no curral durante a noite. Desse modo, a coleta do esterco era praticamente inviabilizada.

Aqui cabe uma digressão: a questão da fertilidade está ligada à transição do processo de uso da terra, ou seja, à passagem do sistema de corte-queima-pousio para o sistema de cultivo contínuo, sem descanso do solo, implicando no aumento da intensidade de uso. Desse modo ela ressulta não apenas da prática de mecanização, mas também 
do uso contínuo da terra - com equipamentos comuns na região como foice, facão e enxada, dado que, também nesse caso se produzem perdas nos rendimentos das culturas e aumento na quantidade de trabalho necessário para a realização das capinas.

Por outra parte, como a maioria dos agricultores não usavam mais que $19 \%$ da área total, não existia uma pressão (estrangulamento do sistema) para abandonar o sistema derruba-queima e adotar um sistema mais intensivo em trabalho e capital.

É importante analisar esse tipo de agricultura quanto ao seu grau de intensidade e seus efeitos sobre o ecossistema. Quando aplicada em áreas de baixa pressão demográfica, como no caso da região Transamazônica, o período de pousio é mais longo, permitindo o desenvolvimento de uma capoeira onde volta a existir um equilíbrio biológico, resultando na recuperação da fertilidade natural (Dubois, 1975). Porém, nas áreas de elevada pressão demográfica $\left(>20\right.$ pessoas $\left./ \mathrm{km}^{2}\right)$, o período de pousio é mais curto, provocando uma rápida degradação do ambiente, especialmente do solo, exigindo assim a entrada de novos processos técnicos (Boserup, 1987). O primeiro caso pode ser considerado como sendo de um sistema de produção racional e estável, harmonicamente adaptado às condições ecológicas requisitando, porém, uma apreciável quantidade de terra para garantir a subsistência de uma população rural.

Preenchida essa condição, somente considerações de sustentabilidade, poderiam sugerir um manejo diferente. Os agricultores estrategicamente poderiam preservar uma parte significativa do terreno, tanto por razões de segurança e equilíbrio do sistema, a mata como elemento regulador do sistema, como reserva de fertilidade, quanto para assegurar um patrimônio para os filhos. Nesse caso a terra com mata representa uma reserva de valor, onde a perspectiva econômica está estreitamente associada à fertilidade natural, demonstrando que na racionalidade camponesa não há uma separação entre "fertilidade agronômica" e "fertilidade econômica" (Reboul, 1989) ${ }^{10}$, ao contrário elas se fundem numa única perspectiva: a da reprodução familiar. Além disso, é possível presumir que preservar a terra assume para os agricultores um grande valor, como reação às suas experiências anteriores de destituídos e expropriados (Martins, 1991).

${ }^{10}$ Trata-se, com efeito, de uma livre interpretação do que é exposto pelo autor mencionado. 


\section{b.5) Uso da mecanização}

Apenas cinco agricultores estavam usando a tração animal, dois deles trabalhando também com a motomecanização. Quatro usavam o trator, sendo que dois, tinham, além do trator, um minitrator de duas rodas (Tobatta). Dois tratores de 4 rodas e um de 2 rodas estavam parados. Um trator e um minitrator estavam sub-utilizados sendo usados somente para o transporte (Quadro 8).

Somente dois agricultores usavam a tração animal para o preparo do solo e capina nas culturas temporárias e/ou no pimental. Em quatro propriedades a tração animal era utilizada para o transporte. Devido às distâncias enormes na região, o transporte acontecia mais no interior da propriedade, com uma extensão de $2.500 \mathrm{~m}$ (1 lote). Como a maioria dos entrevistados tinha uma área maior, o transporte entre os lotes também poderia ter um papel importante.

Para os agricultores mais integrados na economia de mercado e com uma visão mais mercantil (Roy, 1998), a mecanização, além do transporte, poderia facilitar a capina nas culturas perenes, no caso do cacau (mais na fase inicial de estabelecimento da cultura), do café e da pimenta-do-reino, além de permitir o manejo com leguminosas de cobertura e adubação verde.

Quadro 8- Uso da mecanização entre os agricultores entrevistados

\begin{tabular}{|c|c|c|c|c|}
\hline & Total & Preparo de solo & Capina & Transporte \\
\hline $\begin{array}{c}\text { Tração } \\
\text { Animal }\end{array}$ & 5 & 1: uso regular & 2: uso regular & $\begin{array}{c}\text { 2: uso regular } \\
\text { 2: pouco uso }\end{array}$ \\
\hline & & & & $\begin{array}{c}\text { 2: uso regular } \\
\text { 2: uso médio } \\
\text { Trator }\end{array}$ \\
& 4 & 1: pouco uso & - & pouco uso \\
\hline
\end{tabular}

Fonte: Schmitz e Simões (1994)

Entre os agricultores que não usavam a tração animal haviam três que já tinham usado essa tecnologia na Transamazônica, mas abandonaram-na. Como os agricultores no início da colonização só produziam culturas anuais, principalmente arroz, a tração animal, uma tecnologia que eles trouxeram da sua região de origem (um agricultor trouxe até 4 carretas) era mais comum.

Dois agricultores não usavam mais o trator, um abandonou o Tobatta. O trator hoje estava sendo mais utilizado para o transporte do que para o preparo do solo. Tais fatos indicaram que a tendência predominante era o abando da mecanização. 
c) Notas sobre condições e custos da mecanização

c.1) Custo de uso de um trator a preços vigentes no mercado de Altamira em 1994:

Tipo de Trator: VALMET 285 com 85 cavalos de potência (mais adaptado para o trabalho agrícola normal).

Período de demanda máxima pelo trator no preparo da terra para plantio de arroz e milho: meses de novembro e dezembro.

Isso ocorre porquê todos agricultores querem preparar a sua terra no início das chuvas, mesmo com um grande risco do trabalho não ser bom devido o excesso de água (terra úmida demais).

Período de preparo da terra para plantio de feijão: Abril

Tempo de trabalho do trator: 3 meses ou 12 semanas de trabalho agrícola por ano.

Considerando uma intensidade de uso do trator igual a 8h/dia, durante 6 dias na semana, em 12 semanas, temos: 8h/dia x 6 dias x 12 semanas $=576$ horas/ano para o trabalho agrícola.

Durante o resto do ano o trator pode servir para transporte nas vicinais (fora da época das grandes chuvas), no caso de ter uma carreta (3-4 toneladas), ou para tirar madeira.

Nessa forma de uso estimou-se duas semanas por mês, com uma utilização de 8 h/dia durante 5 dias na semana por um período de 6 meses. Teríamos então: 8h/dia x 5 dias x 2 semanas $\times 6$ meses $=480$ horas/ano com outras atividades.

Tempo de uso do trator durante o ano: somando o tempo de trabalho agrícola (576h/ano) com o tempo para outras atividades (480h/ ano) chegamos a um total de 1.056 horas/ano.

Arredondou-se esse valor para 1.000 horas/ano.

Admite-se que o trator, com boa manutenção, terá uma vida útil de 10.000 horas, o que é equivalente a 10 anos, se utilizado 1.000 horas / ano).

a) Os custos fixos

- Amortização

O valor do trator novo é estimado em $\mathrm{R} \$ 25.000,00$, mais os implementos:

Grade de disco: $\mathrm{R} \$ 2.700,00$

Grade niveladora: R\$2.300,00

Carreta: R\$3.000,00

Total Geral: R\$33.000,00. 
Amortização anual: R\$ 33.000/10 anos = 3300/ano

Considerando 1000 h/ano a amortização seria:

$\mathrm{R} \$ 3.300,00 / 1000=R \$ 3,30$ /hora

- Seguro e taxas diversas $=\mathrm{R} \$ 1.000,00$ o que eqüivale

a $R \$ 1,00 /$ hora

- Salários do motorista/mecânico e da pessoa que administra o trator (contabilidade, organização do trabalho, etc.)

Um bom motorista/mecânico:3 salários mínimo x R\$ 70,00 x 12 meses $=\mathrm{R} \$ 2.520,00$

Um gerente (1/2 tempo): 5 salários mínimos $\times \mathrm{R} \$ 70,00 \times 12 / 2=$ $\mathrm{R} \$ 1800,00$

Custo total com salários: $\mathrm{R} \$ 4320,00 / 1000 \mathrm{~h}=R \$ 4,32 /$ hora

Encargos sociais sobre os salários: R\$ 1.000,00 equivalente

a $R \$ 1,00 /$ hora

- Custos administrativos: $\mathrm{R}$ \$ 100,00/mês x 12 meses

$=\mathrm{R} \$ 1.200,00 / 1000 \mathrm{~h}=R \$ 1,20 /$ hora

Total dos custos fixos:R\$10.820,00/ano ou R\$10,82/hora

b) Os custos variáveis

- Custo do combustível e do óleo:

Combustível (diesel) : 7,5 l/hora x R 0,29/1 $=R \$ 2,10 /$ hora

Óleo e filtro (a cada 100 horas): $\mathrm{R} \$ 41,00 / 100=R \$ 0,41 /$ hora

Óleo de transmissão (cada 300 horas): R\$ 135,00/300

$=R \$ 0.19 /$ hora

- Pneus: 2 pneus a cada 2000 horas: R\$ 2.200,00/2000

$=R \$ 1,10 /$ hora

(Observação: Isso depende muito do tipo de preparo da terra e do cuidado do motorista)

- Manutenção anual (troca de peças, etc...) e custos de oficina: equivalente a 50\% da amortização, tem-se então: $\mathrm{R} \$ 3.300,00 / 2=\mathrm{R} \$$ $1.650,00 /$ ano o que é equivalente a $R \$ 1,65 /$ hora.

Total de custos variáveis: $R \$ 5,45 /$ hora

Custo total de uso do trator: custo fixo + custo variável

$=R \$ 16,27 /$ hora

Isso significa que considerando que o custo normal de aluguel de um trator é de $\mathrm{R} \$ 20,00 /$ hora, uma associação poderia cobrar $\mathrm{R} \$ 18,00$ ou R\$ 19,00/hora dos associados para ter uma margem de segurança. É importante dizer aqui que as horas de deslocamento entre roças também deveriam ser pagas. 
Outra observação importante: considerando a hipótese de o trator ser "de graça" para a associação, e que ela decide não amortizar, isso só reduz o custo horário em $\mathrm{R} \$ 3,30$, quer dizer o agricultor tem que pagar no mínimo R \$13,00/hora, sem contribuir para nenhum fundo de segurança para a associação.

\section{c.2) Uso do trator e custo para o agricultor}

Um trator desse tipo (conhecido na região como "jirico") não pode ser usado para desmatar (enleiramento). É necessário para isso alugar um trator de esteira, que custa R \$ 50,00/hora. Dependendo do estado da juquira, o trator de esteira irá gastar entre 3 e 8 horas por hectare, representando um custo de R\$150,00 até R\$ 400,00/ha. Além de ser caro, não é muito bom usar lâmina reta, que destrói a camada superficial do solo. É recomendado usar a lâmina de garfo, que tira as raízes sem arrastar a terra. Depois tem mais o trabalho de limpeza (catação de raízes). A outra alternativa seria o uso de máquinas de cabo manual (talha "Tir-for") para destocar manualmente. É uma boa solução porque custa menos e não prejudica a terra, porém é necessário pelo menos duas pessoas para manusear esse equipamento.

No primeiro ano, o agricultor irá levar entre 5 a 10 dias para catar e tirar as raízes, e terá que fazer duas gradagens, de 3 a 4 horas cada uma. (7 horas em média por hectare) para amansar a terra. Se o trator custa R\$ 20,00/hora, o custo será de R\$ 140,00.

No total, o agricultor investirá entre R\$ 290,00 (caso de um pasto ligeiramente sujo) até R \$ 540,00 (caso de um juquirão) para mecanizar um hectare. É um investimento pesado para as condições médias dos agricultores da região.

Nos anos seguintes, o tempo de trabalho diminui à medida que a terra "amansa" (eliminação das raízes): Poderá ficar numa média de 5 horas por hectare. É melhor gradear logo após a primeira colheita para replantar uma segunda cultura (feijão por exemplo, ou culturas de leguminosas para adubo verde), facilitando o trabalho do solo no ano seguinte (uma gradagem pode ser suficiente se o terreno estiver limpo). Porém, é necessário investir na adubação e na correção do solo depois de 2-3 anos para manter a fertilidade e os rendimentos, com exceção, possivelmente, da terra roxa.

\section{c. 3) Número de produtores atendidos}

Cada agricultor que quiser mecanizar 5 ha (01 alqueire), precisará de 35 horas de trator só para a gradagem. Admitindo que há mãode-obra suficiente para limpar (catar raízes) no mesmo momento em 
que o trator está trabalhando, e que não haverá parada no trabalho do trator (o que não é tão comum), isso representará no mínimo 4 dias de trabalho. Acrescentando meio dia para o deslocamento entre os lotes e meio dia para manutenção e imprevistos, durante os três meses de preparação do solo o trator poderia atender no máximo 14 agricultores (3 meses $\times 4$ semanas $\times 6$ dias por semana $=72$ dias $/ 5=14$ ).

Considerando que depois do primeiro ano, é possível realizar a preparação do solo num tempo menor ( $5 \mathrm{~h} / \mathrm{ha}$ ) e que com uma boa organização é possível trabalhar 10 horas/dia, 6 dias por semana (com 2 motoristas), e limitar o tempo de deslocamento em 5 horas por agricultor, seria possível atender no máximo 2 agricultores por semana, ou seja, um total 24 em 3 meses.

\section{Conclusões}

Em síntese, essa pesquisa teve como resultado principal, nas entrevistas com os agricultores, a confirmação da maior parte das hipóteses:

a) A identificação da fertilidade do solo como fator limitante, sendo que o único método utilizado de manejo da fertilidade era o sistema de pousio prolongado (capoeiras acima de quatro anos) como parte do sistema de corte e queima.

b) Os agricultores entrevistados, em geral, ainda tinham à sua disposição uma área suficiente para continuar com a agricultura itinerante. Nesse caso, a mecanização não contribuía para o aumento do rendimento do trabalho;

c) Remuneração baixa do trabalho não compensando a utilização da mecanização associada ao manejo com fertilizantes químicos.

d) Na produção para o mercado dominavam as culturas perenes. A pecuária estava crescendo e as culturas anuais (culturas alimentares), normalmente o principal motivo da mecanização, eram produzidas apenas para o próprio consumo;

A mecanização, assim, pelas razões mencionadas, sofria uma falta de demanda e apenas era usada de maneira muito limitada - foram encontrados tratores e implementos abandonados durante o levantamento -, apesar da experiência verificada dos agricultores entrevistados e da capacidade em lidar em essa tecnologia.

Porém, esses resultados devem ser relativizados, considerando os seguintes aspectos:

a) Existiam fatores vantajosos ao uso da mecanização, especialmente com tração animal: a existência de bois e pastos; a expe- 
riência dos agricultores com mecanização adquirida em outras regiões; a existência de uma visão mais mercantil a procura de um melhor padrão de vida (Roy, 1998) que se traduz num esforço para conquistar créditos (Sebastian, 1996) e pelas melhorias nas condições de comercialização e; principalmente, a existência de um debate emergente sobre a gestão do território e o "lote dos sonhos" que revelava o interesse dos agricultores em manter a floresta como reserva, ter uma área mecanizada para a produção de culturas anuais. O fato dos agricultores não terem incluído a capoeira no "lote dos sonhos", componente importante da técnica de pousio, denuncia que há o interesse de mudar o sistema, passando para a agricultura permanente.

b) Existia uma "demanda", por parte da sociedade local representada pelas organizações de desenvolvimento, técnicos e agricultores, para a introdução da mecanização e um acompanhamento desse processo pela pesquisa (EMATER, 1993; Relatório, 1994; Simões, 1996a; Schmitz, 1996).

c) As obras estudadas sobre a evolução dos sistemas de produção correspondiam a uma realidade diferente. A dinâmica na Amazônia pode ser outra completamente diferente. A análise do sistema agrário aponta para o processo de concentração fundiária e formação de pastagens ("pecuarização"), ou seja, a lógica pioneira e extensiva que prevalece numa frente pioneira em expansão é contraditória aos processos desencadeados pelo aumento da densidade demográfica. Além disso, a proibição do desmatamento de floresta densa, conforme Walker et al. (1997), tem feito com que capoeiras sejam utilizadas para o plantio de culturas de subsistência e, logo após, o plantio da pastagem, inviabilizando o processo de sustentabilidade no lote.

d) Haviam agricultores, que independentemente da pesquisa, estavam praticando a tração animal sem ser observado um fracasso visível. O conhecimento desses agricultores poderia apontar soluções que permitissem o uso dessa tecnologia, garantindo assim, o resgate do saber dos agricultores. 


\section{Referências Bibliográficas}

BOSERUP, E. Evolução agrária e pressão demográfica. São Paulo, Hucitec/Polis, 1987, 141p.

CASTELLANET, C.; SIMÕES, A.; CELESTINO FILHO, P. Diagnóstico preliminar da agricultura familiar na Transamazônica: pistas para pesquisa-desenvolvimento. Belém, Embrapa Amazônia Oriental, 1997.

CERRI, C. C.; VOLKOFF, B.; ANDREAUX, F. Nature and behaviour of organic matter in soils under natural forest and after deforestation near Manaus. Forest Ecology and Management, 38. 1991, p. 247257.

CHAYANOV, A. V. La organización de la unidad económica campesina. Buenos Aires, Ediciones Nueva Visión, 1974, 342p.

DARRÉ, J-P. L 'invention des pratiques dans l'agriculture: vulgarisation et production locale de connaissance. Paris, Karthala, 1996, 194p.

DENICH, M. Estudo da importância de uma vegetação secundária nova para o incremento da produtividade do sistema de produção na Amazônia Oriental Brasileira. Eschborn:Belém, GTZ:EMBRAPA/ CPATU, 1991, 284p. (Tese de doutorado).

DERPSCH, R.; ROTH, C. H.; SIDIRAS, N.; KÖPKE, U. Controle da erosão no Paraná, Brasil: sistemas de cobertura do solo, plantio direto e preparo conservacionista do solo. Eschborn, GTZ; IAPAR, 1991, $268 \mathrm{p}$.

DUBOIS, J. Los sistemas de produccion mas apropriados para el uso racional de las tierras de la Amazônia. 1975, 59p. mimeografado.

EDEN, M. J.; FURLEY, P. A.; McGREGOR, D. F. M.; MILLIKEN, W.; RATTER, J. A. Effect of forest clearence and soil burning on soil properties in northern Roraima. Forest Ecology and Management, 39. 1991, p. 283-290.

EMATER. Programa de Produção de Alimentos. Projeto: Mecanização Agrícola. Altamira, EMATER, 1993, 15p. 
FERREIRA, F. J.; FERREIRA, L. A.; MOREIRA, I. S. A localidade do "travessão da 8" no município de Altamira-Pará. Belém, UFPA/NEAF/ DAZ, 1994.

FLOHRSCHÜTZ, G. H. H. Análise econômica de estabelecimentos rurais no Município de Tomé-Açu, Pará: um estudo de caso. Belém, EMBRAPA-CPATU, 1983, 44p. (Documentos, 19).

HAMELIN, P. O fracasso anunciado. In: LÈNA, P.; OLIVEIRA, A. E. de (orgs.) Amazônia: a fronteira agrícola 20 anos depois. Belém, MPEG/ ORSTOM, 1991, p. 161-176.

KITAMURA, P.C. Agricultura migratória na Amazônia: um sistema de produção viável? Belém, EMBRAPA-CPATU, 1982, 20p. (Documentos, 12)

MARTINS, J. de S. Expropriação e violência: a questão política no campo. $3^{a}$ ed. São Paulo, Hucitec, 1991, 182p.

MARTINS, P. F. da S. Análise crítica sobre a pesquisa agronômica aplicada na Amazônia. Belém, NAEA/UFPA, 1992, 7p. (Paper, 3)

PIMENTEL, G.B.M.; REIS, A.F.S; PALHETA, R. de F.R. Tração animal: uma experiência piloto no Pará. Belém, EMBRAPA-CPATU, 1992, $11 \mathrm{p}$.

PINGALI, P.; BIGOT, Y.; BINSWANGER, H. P. Agricultural Mechanization and the Evolution of Farming Systems in Sub-Saharan Africa. Baltimore, The John Hopkins University Press, The World Bank, 1987, $216 \mathrm{p}$.

REBOUL, C. Monsieur le capital et madame la terre: fertilité agronomique et fertilité économique. Paris, Edi-INRA, 1989, 253p.

RELATÓRIO DA $1^{\text {a }}$ CONFERÊNCIA MUNICIPAL URUARENSE SOBRE PROJETOS ECONÔMICOS ALTERNATIVOS, 10-13/03/94. Relatório final. Uruará, 1994, 66p.

ROY, G. A agricultura familiar nas frentes de colonização da Transamazônica: ensaio crítico sobre as abordagens agroeconômicas. Seminário sobre Métodos e Experiências de Pesquisa-Formação-Desen- 
volvimento em Agricultura Familiar, 26-27/11/98. Belém, NEAF/ CAP/UFPA, 1998, 21p. mimeografado.

RUTHENBERG, H. Farming Systems in the Tropics. $3^{\text {a }}$ ed. Oxford, Clarendon Press, 1980, 424p.

SCHMITZ, H.; CASTELLANET, C.; SIMÕES, A. Participação dos agricultores e de suas organizações no processo de desenvolvimento de tecnologias na região da Transamazônica. Antropologia, Vol. 12, No. 2. Belém, MPEG, 1996, p. 201-246. (Boletim do Museu Paraense Emílio Goeldi).

SCHMITZ, H. Desenvolvimento participativo de tecnologias: a experiência de mecanização na Transamazônica. Agricultura Familiar, Vol. 1, No. 1. Belém, NEAF/CAP/UFPA, 1996, p.1-20.

SCHMITZ, H; SIMÕES, A. Mecanização na Transamazônica. Altamira, LAET, 1994, 52p. mimeografado (relatório de pesquisa).

SCHMITZ, H.; SOMMER, M.; WALTER S. Animal Traction in Rainfed Agriculture in Africa and South America. Deteminants and Experiences. Braunschweig, Vieweg, 1991, 311p.

SEBASTIAN, F. Levantamento do FNO especial no Estado do Pará. Belém, FETAGRI, 1996, 54p. mimeografado.

SÉBILLOTTE, M. Approaches of the on-farm agronomist: some methodological considerations. Thailand National Farming Systems Seminar. Thailand, Prince of Songkla University, Haad Yai, 1987.

SÉBILLOTTE, M. Itinéraires techniques et évolution de la pensée agronomique. C.R. Académie d'Agriculture de France, No. 2. Paris, 1987, p. 906-914.

SIMÕES, A. A construção da pesquisa-desenvolvimento participativa: reflexões sobre a introdução da mecanização na Transamazônica. Agricultura Familiar, Vol.1., No.1. Belém, NEAF/CAP/UFPA, 1996a, p. 59-79.

SIMÕES, A. Transamazônica: evolução, diversidade e possibilidades de desenvolvimento. Simpósio Internacional Amazônia XXI. Agenda 
e Estratégias de Sustentabilidade, 14-17/09/97. Belém, NAEA/ UFPA; UNAMAZ, 1997. mimeografado.

THIOlLENT, M. Metodologia da pesquisa-ação. 6 ${ }^{\mathrm{a}}$ ed. São Paulo, Cortez, 1994, 108p.

VEIGA, J.B.; TOURRAND, J.F. G QUANZ, D. A pecuária na fronteira agrícola da Amazônia: o caso do município de Uruará-PA. Belém: EMBRAPA-CPATU, 1995, 55p.

WALKER, R.T.; HOMMA, A.K.O.; CONTO; A. J. do. et al. As contradições do processo de desenvolvimento agrícola na Transamazônica. Belém, Embrapa Amazônia Oriental, 1997, 107p. (Documentos, 93). 